\title{
Synergistic effect of animal oil or butter and hydrogen peroxide on physical and mechanical properties of porous alumino-siliceous materials
}

\author{
Narumon Lertcumfu ${ }^{\mathrm{a}}$, Kannikar Kaewapai ${ }^{\mathrm{a}, \mathrm{b}}$, Pharatree Jaita ${ }^{\mathrm{a}, \mathrm{c}}$, Ratabongkot Sanjoom ${ }^{\mathrm{d}}$, \\ Gobwute Rujijanagul ${ }^{a, c, e, f, *}$, Tawee Tunkasiri ${ }^{\mathrm{a}, \mathrm{c}}$ \\ a Department of Physics and Materials Science, Faculty of Science, Chiang Mai University, Chiang Mai \\ 50200 Thailand \\ b Graduate School, Chiang Mai University, Chiang Mai 50200 Thailand \\ c Science and Technology Research Institute, Chiang Mai University, Chiang Mai 50200 Thailand \\ ${ }^{d}$ Department of Applied Science and Biotechnology, Faculty of Agro-Industrial Technology, Rajamangala \\ University of Technology Tawan-ok Chantaburi Campus, Chantaburi 22210 Thailand \\ e Materials Science Research Center, Faculty of Science, Chiang Mai University, Chiang Mai, Thailand \\ f Research Center in Physics and Astronomy, Faculty of Science, Chiang Mai University, Chiang Mai 50200 \\ Thailand
}

*Corresponding author, e-mail: rujijanagul@yahoo.com

Received 16 Oct 2019

Accepted 18 Dec 2019

\begin{abstract}
Porous alumino-siliceous (PAS) materials are attractive for use in a wide variety of construction and adsorption materials. In the present study, the porous alumino-siliceous materials were synthesized by a geopolymerization method in a reaction from ceramic waste, metakaolin, and an alkaline solution, $\mathrm{H}_{2} \mathrm{O}_{2}$ (as a foaming agent) and either pork lard or butter (surfactants). Different amounts of the surfactants (2.5-15 wt\%) were added to the samples. The pore shape in the PAS materials was affected by the type of surfactant used. PAS materials with small open pores and high porosity were successfully fabricated with butter as a surfactant. The compressive strength value trend was related to total porosity. The relationship between compressive strength and porosity was found to be consistent with a model proposed by Ryshkewitch. The results suggest that this material can be used as a foam material.
\end{abstract}

KEYWORDS: porous alumino-siliceous materials, animal oil, butter, hydrogen peroxide

\section{INTRODUCTION}

Alumino-siliceous materials are pozzolanic materials containing reactive silica and alumina [1]. Pozzolanic materials are well known as construction materials, wastes, and ashes produced from some agricultural materials, e.g., metakaolin, calcined clays, fly ash, slag, rice husk, sawdust, palm kernel shells, and sugarcane bagasse [1-3]. Pozzolanic materials have been used as precursors for geopolymer materials, which are obtained by the reaction of aluminosilicates with a highly alkaline environment, leading to the formation of a continuous threedimensional network of inorganic molecules linked by covalent bonds [4]. These structures are composed of one tetrahedral silicate and aluminate units that are connected to each other by sharing one common oxygen atom [4-6]. Geopolymer materials is one of the most promising alternative materi- als, which was first discovered by Davidovits [7]. Geopolymer materials are attractive because of their good chemical resistance, high-temperature resistance, high early strength, high durability, thermal stability, low shrinkage, lightweight, low cost, and environmental friendliness [8-13]. All of the advantageous properties of geopolymer materials make them very interesting materials for forming geopolymer foams.

Geopolymer foams (porous alumino-siliceous materials, PAS) are lightweight materials consisting of geopolymer paste with a high degree of a homogeneous void, or pore structure, inside the materials due to small air bubbles having been introduced to the geopolymer matrix. Controlling the pore structure (i.e., shape, morphology, and size), total porosity, and pore size distribution are important parameters for generating geopolymer foams, for which the voids and pores determine the density 
and strength [14-16]. PAS materials have been applied in many applications such as for photocatalytic degradation, membranes, high-efficiency adsorption materials, and building materials $[16,17]$.

To fabricate the foam, pore foaming agents such as silicon [18] metallic aluminum powder [19], and $\mathrm{H}_{2} \mathrm{O}_{2}$ [16-19] are used to produce the air bubbles in geopolymer foams. However, these pore foaming agents often create closed pores which reduce the total surface area of the sample. This can make them unsuitable for some applications. To solve this problem, stabilizing agents such as surfactants, fibers, and particles can be used for addition into the geopolymer slurry to decrease the surface tension of the gas/slurry system $[20,21]$. Surfactants such as Triton X 100 [22], Tween 80 [21], protein [23], and vegetable oil $[16,24]$ are classified in the hydrophilic group and are used for this purpose. One of the interesting surfactants is oil due to its lower cost than the pure chemical of surfactants, and the result from previous researches $[16,24]$ reported that the reaction between high alkaline geopolymer and fatty acid in oils via a saponification reaction can create the interconnect porous [25]. Typical properties of the fatty acid collected from the literature are given in Table 1. A typical representation of fatty acid compositions is $\mathrm{C}_{x: y}$ in which $x$ is the number of carbons, $y$ is the number of double bonds. Generally, $\mathrm{C}_{16: 0}$ (Palmitic acid) is the most common saturated fatty acid in animals, plants, and microorganisms, and $\mathrm{C}_{18: 1}$ (Oleic acid) is the most common monounsaturated fatty acid in plants, animals and microorganisms [26].

Recently, the properties of geopolymer foams that contain vegetable oil as a surfactant and $\mathrm{H}_{2} \mathrm{O}_{2}$ as a foaming agent have been reported $[16,24]$. It has been proposed that the type of vegetable oil slightly affected the total porosity, average pore size, and pore size distribution, but significantly affected the compressive strength of the samples. In the present work, we demonstrate that animal oil or products from animals can be used as alternative surfactants. Furthermore, data for products from animals as geopolymer surfactants is lacking. Therefore in the present work, geopolymer foam was fabricated. The synergistic effects of animal oil or butter as a surfactant and hydrogen peroxide as a foaming agent were investigated. To reduce industrial waste, ceramic waste from a ceramic factory was used as a raw material in this work.

\section{MATERIALS AND METHODS}

Ceramic waste (CW, or calcined clays) from A.P.K Dewkoo (from Ang Thong province, Thailand) and kaolinite (from Ranong province, Thailand) were used as raw materials to fabricate porous aluminosiliceous materials. The ceramic waste was crushed into a fine powder by grinding, using mortar and ball milling technique. Kaolinite was calcined at $750^{\circ} \mathrm{C}$ for $3 \mathrm{~h}$ to obtain metakaolin (MK) and then crush into a fine powder using a ball milling technique. Chemical analysis was performed with an X-ray Fluorescence (XRF) technique. To form the porous alumino-siliceous materials, a $15 \mathrm{M} \mathrm{NaOH}$ solution was prepared by dissolving sodium hydroxide (98\% purity sodium hydroxide, the brand name of Praatit) with deionized water for at least $24 \mathrm{~h}$ at room temperature to complete the exothermic reaction. Sodium silicate $\left(\mathrm{Na}_{2} \mathrm{SiO}_{3}\right)$ was purchased from World Chemical Industrial (Thailand) with the chemical composition of $16.32 \% \mathrm{Na}_{2} \mathrm{O}, 34.60 \%$ $\mathrm{SiO}_{2}$ and $49.08 \% \mathrm{H}_{2} \mathrm{O}$ (mole ratio $\mathrm{SiO}_{2} / \mathrm{Na}_{2} \mathrm{O}$ $=2.19$ ) and with a specific gravity at $20^{\circ} \mathrm{C}$ of $1.54 \mathrm{~g} / \mathrm{cm}^{3}$. The $\mathrm{Na}_{2} \mathrm{SiO}_{3}$ solution was diluted with water $\left(61 \% \mathrm{Na}_{2} \mathrm{SiO}_{3}^{+} 49 \% \mathrm{H}_{2} \mathrm{O}\right)$ and mixed by stirring for $24 \mathrm{~h}$. The $\mathrm{NaOH}$ and $\mathrm{Na}_{2} \mathrm{SiO}_{3}$ solution were mixed to prepare the alkaline activator solution and left to cool down to room temperature. Hydrogen peroxide $\left(\mathrm{H}_{2} \mathrm{O}_{2}\right)$ was used as the foaming agent. $\mathrm{H}_{2} \mathrm{O}_{2}$ with a concentration of $30 \mathrm{wt} \%$ was diluted with water to $3 \mathrm{wt} \%$. A $0.24 \mathrm{wt} \%$ solution of diluted $\mathrm{H}_{2} \mathrm{O}_{2}$ (3 wt\%) was used to substitute some of $\mathrm{Na}_{2} \mathrm{SiO}_{3}$. Butter and pork lard (Unsalted butter, Orchid) was used as a surfactant, ranging from being 2.5-15 wt\% of the sample. To prepare the pork lard, pork fat was heated on a cast-iron skillet, keeping the heat below the fat's smoke point until pork lard was obtained. To form the PAS samples, the ratios of the mixtures of ceramic waste/MK and $\mathrm{Na}_{2} \mathrm{SiO}_{3} / \mathrm{NaOH}$ were 1.4 and 1.14 , respectively. The PAS materials were prepared in the following manner. First, ceramic waste and metakaolin were mixed together. The obtained powder was then mixed together with the alkaline solution. Butter and pork lard were heated up to $35^{\circ} \mathrm{C}$ to get a liquid, and then $3 \mathrm{wt} \%$ of $\mathrm{H}_{2} \mathrm{O}_{2}$ with either pork lard or butter were added into the slurry. The mixture contents were mixed together until a homogeneous slurry was obtained. The slurry was then poured into a cube-shaped plastic mold $(1.5 \times 1.5 \times 1.5 \mathrm{~cm})$ which was vibrated for $5 \mathrm{~min}$ and cured at room temperature. Finally, the residual pork lard and butter was removed by soaking the PAS material in 
Table 1 Fatty acid compositions of vegetable oil, pork lard, other animal fats, and products from live animals [26-34].

\begin{tabular}{|c|c|c|c|c|c|c|c|c|c|c|c|}
\hline \multirow{2}{*}{ Source } & \multicolumn{11}{|c|}{ Fatty acid $(\% \mathrm{w} / \mathrm{w})$} \\
\hline & $\mathrm{C}_{12: 0}$ & $\mathrm{C}_{14: 0}$ & $\mathrm{C}_{16: 0}$ & $\mathrm{C}_{16: 1}$ & $\mathrm{C}_{17: 0}$ & $\mathrm{C}_{18: 0}$ & $\mathrm{C}_{18: 1}$ & $\mathrm{C}_{18: 2}$ & $\mathrm{C}_{18: 3}$ & $\mathrm{C}_{20: 0}$ & $\mathrm{C}_{20: 1}$ \\
\hline Olive oil & - & 0.7 & 11.5 & - & - & 2.0 & 78.6 & 7.0 & - & 0.2 & - \\
\hline Sunflower oil & - & - & 3.7 & - & - & 2.0 & 31.5 & 60.5 & - & 2.3 & - \\
\hline Pork lard ${ }^{\mathrm{a}}$ & - & 1.5 & 25.4 & 2.4 & - & 13.3 & 41.4 & 13.4 & - & - & - \\
\hline Pork lard ${ }^{\mathrm{b}}$ & - & 1.3 & 20.6 & 1.9 & 0.5 & 10.9 & 39.1 & 19.6 & 1.2 & 0.9 & 0.9 \\
\hline Beef tallow & 2.0 & 6.0 & 28.0 & - & - & 22.0 & 38.0 & 3.0 & 1.0 & - & - \\
\hline Beef fat & - & 2.9 & 24.5 & 2.8 & 1.3 & 17.8 & 28.6 & 1.8 & 0.8 & 0.1 & 0.2 \\
\hline Chicken fat & - & 0.9 & 28.3 & 5.8 & 0.2 & 6.7 & 41.1 & 14.3 & 0.6 & 0.1 & \\
\hline Mutton fat & - & 6.7 & 20.7 & 0.9 & 2.0 & 28.0 & 33.9 & 1.3 & 0.8 & 0.6 & 0.1 \\
\hline Cod liver oil & - & 4.2 & 11.9 & 6.9 & 0.2 & 2.3 & 21.1 & 0.4 & 1.9 & 0.1 & 11.4 \\
\hline Butter & 3.9 & 12.9 & 31.4 & 2.0 & - & 12.1 & 30.2 & 2.1 & - & 0.8 & 1.6 \\
\hline Margarine & 0.2 & 1.1 & 48.7 & 0.2 & - & 5.0 & 33.9 & 9.8 & 0.4 & - & - \\
\hline
\end{tabular}

${ }^{a}$ Pork lard from local commerce (São Paulo, Brazil).

${ }^{\mathrm{b}}$ Pork lard from slaughtered houses in Yogyakarta (Indonesia).

hot water $\left(80^{\circ} \mathrm{C}\right)$, which was replaced every $20-40$ min, until it cleared up.

The phase formation of the PAS samples was carried out using an X-ray diffraction technique (XRD). The XRD patterns (2 $\theta)$ were measured in a range from $10-60^{\circ}$. The bulk density, porosity, and water absorption of each PAS sample were determined using Archimedes' method. The data presented are the averages of three replicates. The bulk density, porosity, and water absorption were calculated using the following equations:

$$
\begin{aligned}
\text { Bulk density } & =\frac{W_{\mathrm{d}}}{W_{\text {ssd }}-W_{\mathrm{w}}} \times \rho_{\text {water }} \\
\text { Porosity } & =\frac{W_{\text {ssd }}-W_{\mathrm{d}}}{W_{\text {ssd }}-W_{\mathrm{w}}} \times 100 \\
\text { Water absorption } & =\frac{W_{\text {ssd }}-W_{\mathrm{d}}}{W_{\mathrm{w}}} \times 100
\end{aligned}
$$

where $W_{\text {ssd }}$ is the specimen weight in the saturated surface dry condition $(\mathrm{g}), W_{\mathrm{d}}$ is the specimen dry weight after $24 \mathrm{~h}$ in an oven $(\mathrm{g}), W_{\mathrm{w}}$ is the weight of saturated specimen $(\mathrm{g}), \rho_{\text {water }}$ is the density of water $\left(\mathrm{g} / \mathrm{cm}^{3}\right)$. The total porosity $(p)$ was calculated according to the equation:

$$
p=\left(1-\frac{\rho_{\mathrm{b}}}{\rho_{\mathrm{t}}}\right) \times 100
$$

where $\rho_{\mathrm{b}}$ is bulk density and $\rho_{\mathrm{t}}$ is true density. The microstructure of the samples was investigated with a scanning electron microscope (SEM, JEOL JSM-5910 LV). A mechanical property, i.e., the compressive strength, was tested using compression machines on at least six specimens after curing for 3 days.
Table 2 The major chemical compositions (\%) of ceramic waste, kaolinite, and metakaolin.

\begin{tabular}{lccc}
\hline Oxide & Ceramic waste & Kaolinite & Metakaolin \\
\hline $\mathrm{SiO}_{2}$ & 57.30 & 47.87 & 55.64 \\
$\mathrm{Al}_{2} \mathrm{O}_{3}$ & 12.80 & 36.66 & 38.60 \\
$\mathrm{Fe}_{2} \mathrm{O}_{3}$ & 17.94 & 0.05 & 0.70 \\
\hline
\end{tabular}

\section{RESULTS AND DISCUSSION}

The chemical compositions of ceramic waste, kaolinite, and metakaolin were analyzed with an Xray Fluorescence (XRF) technique. The chemical compositions of the ceramic waste, kaolinite, and metakaolin consisted of many components, e.g., $\mathrm{Al}_{2} \mathrm{O}_{3}, \mathrm{SiO}_{2}, \mathrm{Fe}_{2} \mathrm{O}_{3}, \mathrm{~K} 2 \mathrm{O}, \mathrm{MgO}, \mathrm{Na}_{2} \mathrm{O}$, and $\mathrm{TiO}_{2}$. However, the major components of these materials were $\mathrm{Al}_{2} \mathrm{O}_{3}, \mathrm{SiO}_{2}, \mathrm{Fe}_{2} \mathrm{O}_{3}$, as shown in Table 2. The XRD patterns of PAS materials are shown in Fig. 1. The XRD result revealed that the samples contained a multiphase, including a major phase of quartz and minor phases of rutile $\left(\mathrm{TiO}_{2}\right)$ and hematite $\left(\mathrm{Fe}_{2} \mathrm{O}_{3}\right)$. This result corresponded with the XRF result.

Fig. 2(a-d) and Fig. 3(a-d) show the prototype precasts of PAS samples produced using $\mathrm{H}_{2} \mathrm{O}_{2}$ as a foaming agent, and respectively containing butter or pork lard as different surfactants used in varying amounts. Orange-brown color of the samples was caused by the ceramic waste powders (raw material) containing $\mathrm{Fe}_{2} \mathrm{O}_{3}$. The PAS samples containing butter had higher porosity at the surface, than that of the PAS samples with pork lard. However, the surface porosity was found to increase as the amount of the surfactants increased for both butter and pork lard samples, as shown in Fig. 2(e-h) and Fig. 3(e- 

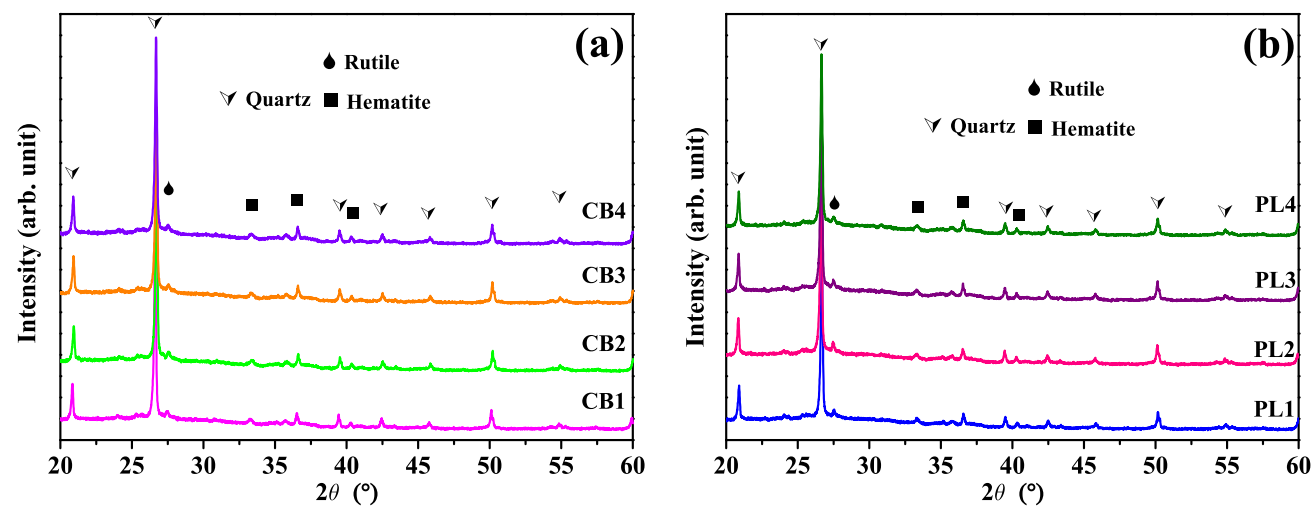

Fig. 1 X-ray diffraction patterns of PAS samples: (a) cow butter as a surfactant and (b) pork lard as a surfactant.

$2.5 \mathrm{wt} \%$

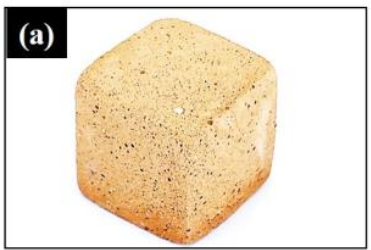

(e)

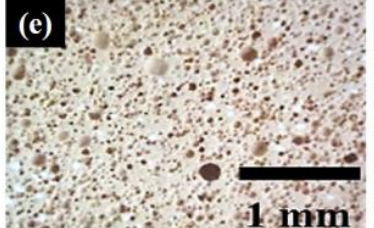

thos $1 \mathbf{m m}^{2}$
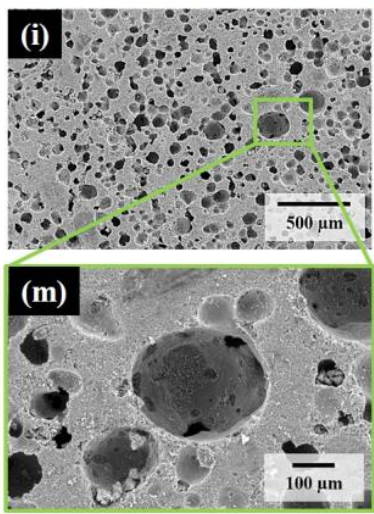

5 wt $\%$

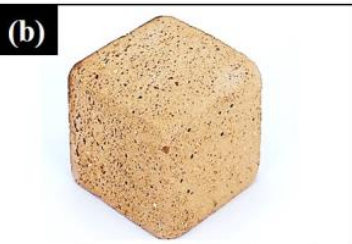

(f)
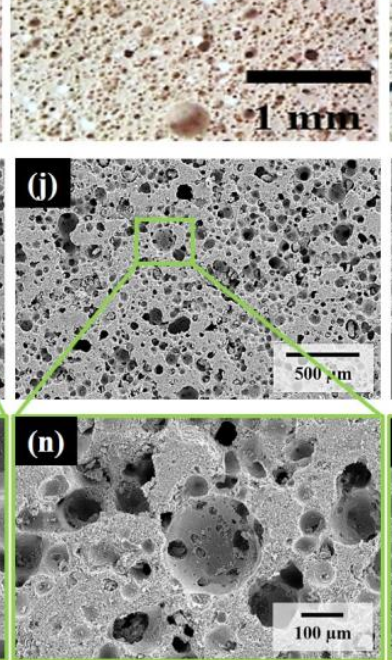

$10 \mathrm{wt} \%$

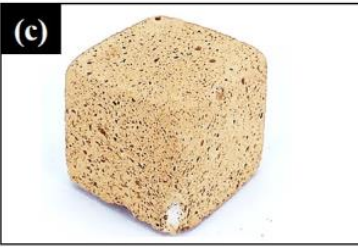

(g)
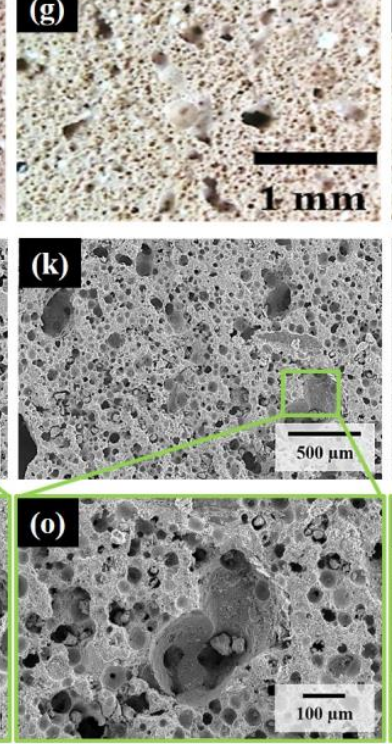

$15 \mathrm{wt} \%$

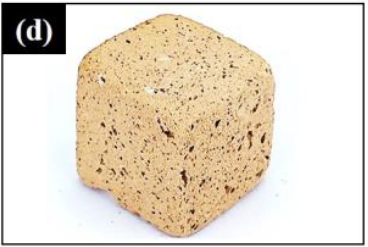

(h)
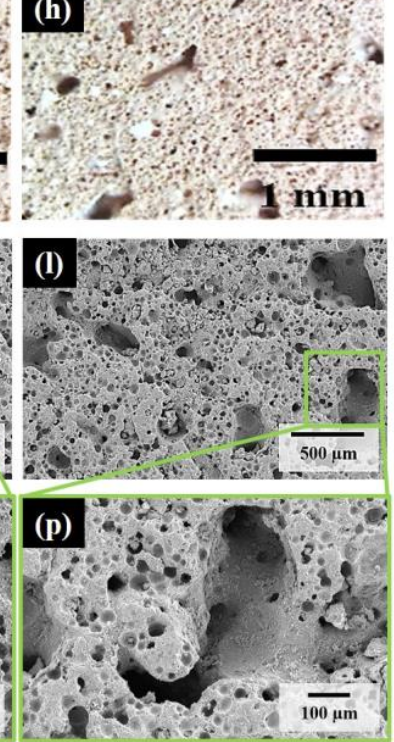

Fig. 2 (a-d) The prototype precasts of PAS samples, (e-h) optical images, (i-l) SEM micrographs, and (m-p) closer examination of the SEM micrographs at selected areas for PAS samples with cow butter as a surfactant.

h), respectively.

The SEM images of PAS samples containing butter and pork lard are shown in Fig. 2(i-p) and Fig. 3(i-p), respectively. The type of surfactant used, with respect to butter and pork lard, was found to have an effect on the morphology of PAS samples which produced well interconnected pores (open pores). Furthermore, the amount of open pores increased as amounts of surfactant increased. As shown in previous works, the morphology of geopolymer foam formed when $\mathrm{H}_{2} \mathrm{O}_{2}$ was used as a foaming agent normally gave large sphere-shaped pores [35]. That is due to $\mathrm{H}_{2} \mathrm{O}_{2}$ reacting with alkaline solutions to generate gas, which causes 


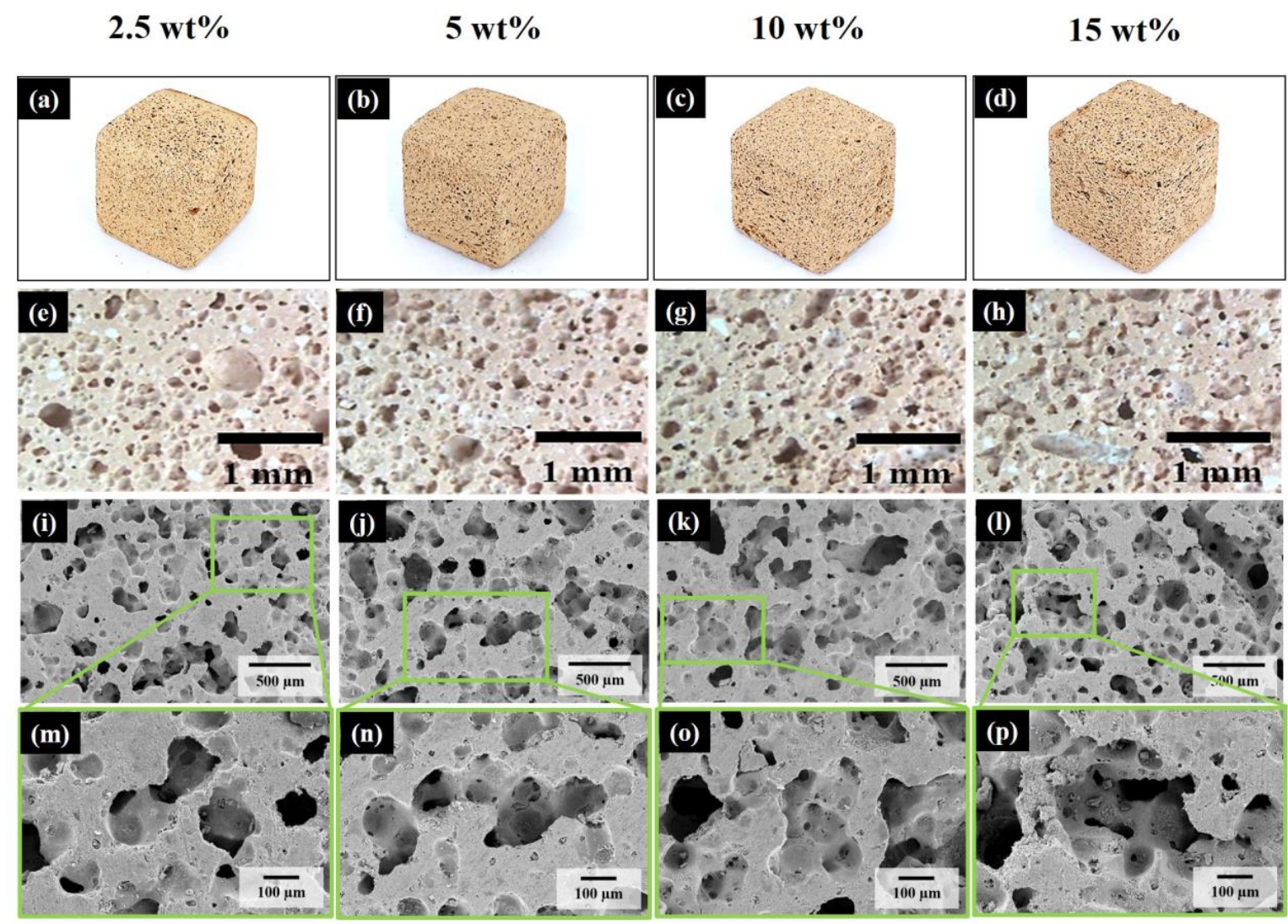

Fig. 3 (a-d) The prototype precasts of PAS samples, (e-h) optical images, (i-l) SEM micrographs, and (m-p) closer examination of SEM micrographs at selected areas for PAS samples with pork lard as a surfactant.

a porous microstructure in the samples [36,37] because $\mathrm{H}_{2} \mathrm{O}_{2}$ decomposes to $\mathrm{H}_{2} \mathrm{O}$ and $\mathrm{O}_{2}$ according to the following equations [36]:

$$
\begin{aligned}
& \mathrm{H}_{2} \mathrm{O}_{2}+\mathrm{OH}^{-} \longrightarrow \mathrm{HO}_{2}^{-}+\mathrm{H}_{2} \mathrm{O} \\
& \mathrm{HO}_{2}+\mathrm{H}_{2} \mathrm{O}_{2} \longrightarrow \mathrm{H}_{2} \mathrm{O}+\mathrm{O}_{2}+\mathrm{OH}^{-}
\end{aligned}
$$

In the present work, the PAS samples that combined $\mathrm{H}_{2} \mathrm{O}_{2}$ as a foaming agent and butter as a surfactant exhibited morphology having a shape similar to what was found in a previous work [24], in agreement with published literature [16,24]. On the other hand, the morphology of pork lard PAS samples exhibited distorted spherical or oblong shapes.

The values of bulk density and total porosity $(p)$ of PAS samples are shown in Table 3. It was found that the pork lard PAS samples exhibited higher values of density than the butter PAS samples. When the amount of surfactant increased, the density value decreased from $0.85-0.71 \mathrm{~g} / \mathrm{cm}^{3}$ and from $0.87-0.75 \mathrm{~g} / \mathrm{cm}^{3}$ for butter and pork lard $(2.5-15$
Table 3 Bulk density and total porosity of PAS samples as a function of the amount of surfactant.

\begin{tabular}{lccccc}
\hline Sample & $\begin{array}{c}\mathrm{H}_{2} \mathrm{O}_{2} \\
\text { (wt\%) }\end{array}$ & \multicolumn{2}{c}{ Surfactant (wt\%) } & Bulk density & Total porosity \\
\cline { 3 - 4 } & & & Pork lard & $\left(\mathrm{g} / \mathrm{cm}^{3}\right)$ & $(\%)$ \\
\hline GCB1 & 2.4 & 2.5 & - & $0.85 \pm 0.02$ & $62.5 \pm 0.3$ \\
GCB2 & 2.4 & 5 & - & $0.80 \pm 0.03$ & $64.5 \pm 0.5$ \\
GCB3 & 2.4 & 10 & - & $0.72 \pm 0.01$ & $67.4 \pm 0.2$ \\
GCB4 & 2.4 & 15 & - & $0.71 \pm 0.01$ & $67.8 \pm 0.1$ \\
GPL1 & 2.4 & - & 2 & $0.87 \pm 0.02$ & $59.3 \pm 0.4$ \\
GPL2 & 2.4 & - & 5 & $0.86 \pm 0.01$ & $61.2 \pm 0.1$ \\
GPL3 & 2.4 & - & 10 & $0.79 \pm 0.03$ & $65.4 \pm 0.3$ \\
GPL4 & 2.4 & - & 15 & $0.75 \pm 0.02$ & $66.9 \pm 0.3$ \\
\hline
\end{tabular}

wt $\%$ samples), respectively. This may be due to the morphology of the pores having agglomerated together to become larger pores at a high amount of surfactant (Fig. 2 and Fig. 3). Fig. 4 shows the values of porosity and water absorption for PAS samples having different amounts of butter and pork lard. Both porosity and water absorption increased as the amount of surfactant increased, which corresponded to the decreases of density 

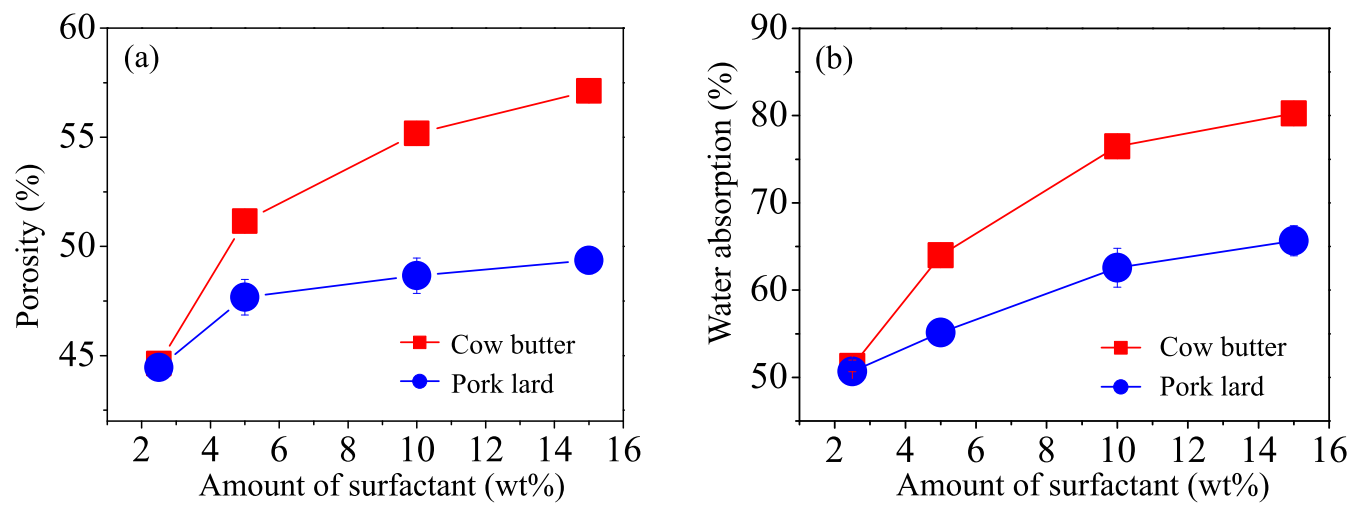

Fig. 4 (a) Porosity and (b) water absorption of PAS samples with varying amounts of surfactant.

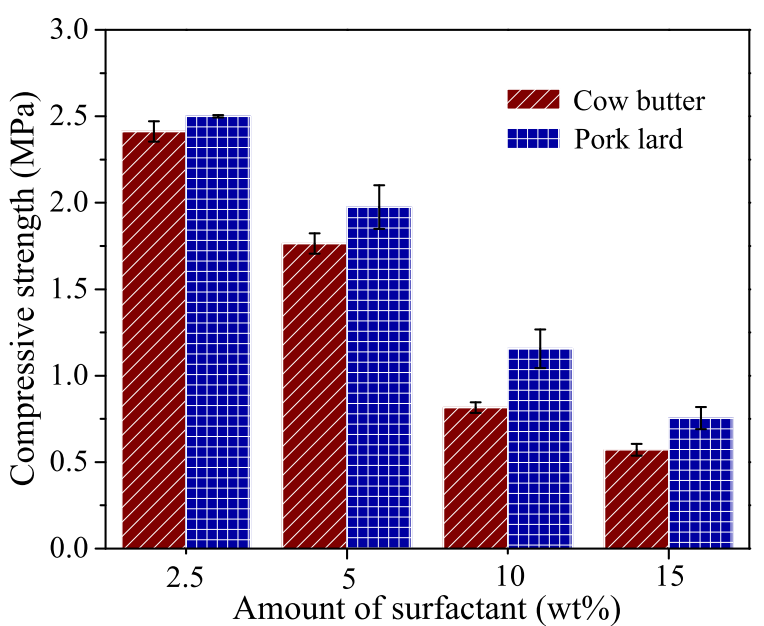

Fig. 5 Compressive strength of PAS samples with varying amounts of surfactant.

value (Table 3). The porosity value increased from $45.16-49.36 \%$ and from $43.14-57.12 \%$ for butter and pork lard, respectively. In the same direction, the water absorption value increased from 50.51$80.26 \%$ and $51.88-65.66 \%$ (2.5-15 wt $\%$ samples), for butter and pork lard, respectively. The butter PAS samples may have had higher porosity and water absorption values at the same amount of surfactant as the pork lard PAS samples because of the different lather properties of the surfactants due to the composition of aliphatic chains producing different types of soap molecules $[24,26]$. Normally, the reaction between oil and a strong alkaline solution produces in situ carboxylate surfactants (soap molecules) via the saponification reaction, which consists of the hydrolysis of the triglycerides (found in oil or fats), plus glyceride, and glycerol (a watersoluble molecule) [25].

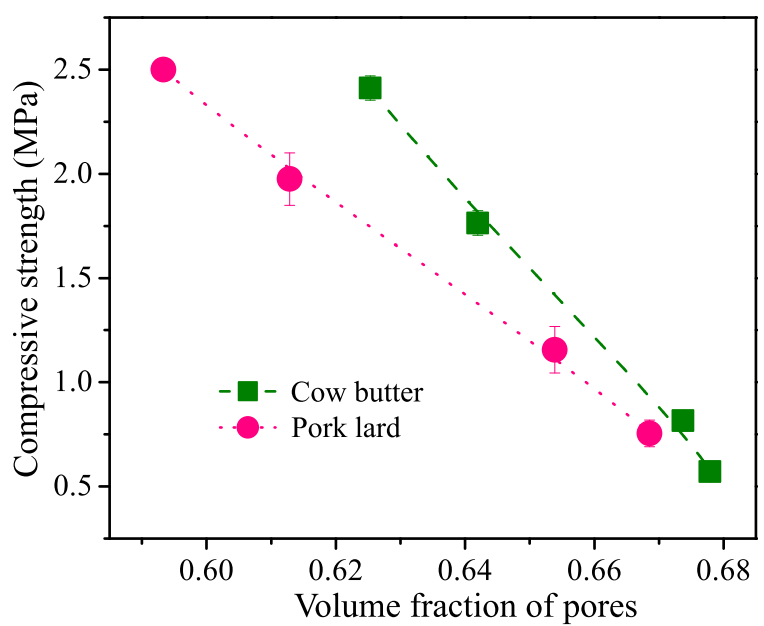

Fig. 6 The plot of compressive strength versus volume fraction of pores for PAS samples.

The compressive strengths of PAS samples are shown in Fig. 5. The compressive strength value decreased when the surfactant content increased. However, the pork lard PAS samples exhibited higher compressive strength than the butter PAS samples, agreeing with the porosity results in which high amounts of porosity decreased compressive strength. Normally, the relationship between strength and total porosity (Table 3) can be explained by several models. However, a simple equation (7) proposed by Ryshkewitch [38] describes the strength $(\sigma)$ of a porous material related to total porosity $(p)[21]$ :

$$
\sigma=\sigma_{0} \mathrm{e}^{b p}
$$

where $\sigma$ is the strength of a material at relative total porosity $p, \sigma_{0}$ is a constant, and $b$ is a parameter determined by pore characteristics. The strength 
and total porosity values data (Fig. 5 and Table 3) were well fitted by the equation (7) as shown in Fig. 6 . The $b$ values for butter and pork lard samples were 25.97 (with a correlation factor $R^{2}=0.95$ ) and $15.18\left(R^{2}=0.96\right)$, respectively. This result is consistent with previous works on porous ceramics $[16,24,39,40]$.

\section{CONCLUSION}

In this work, the porous alumino-siliceous materials were successfully synthesized by geopolymerization using $\mathrm{H}_{2} \mathrm{O}_{2}$ as a foaming agent with different surfactants (butter or pork lard). The type of surfactant used, with respect to butter or pork lard, was found to have an effect on the morphology of the PAS samples, and they produced the open pores. The PAS samples were characterized by large sphereshaped pores when butter was used, and distorted spherical or oblong shaped pores when pork lard was used. This result is due to the lather properties of the different surfactants, and therefore producing different types of soap molecules. The butter provided the best combination, in terms of porosity and water absorption values. The trend of compressive strength was related to porosity, a high amount of pork lard decreased the compressive strength. The relationship between the porosity and strength can be described by the Ryshkewitch model. The PAS materials with animal oil and animal products have a potential for using as highly porous material with wide applications.

Acknowledgements: This research work was supported by the Thailand Research Fund (TRF, BRG6080002), the Research and Researchers for Industries (RRI), National Research Council of Thailand and a partial support from Chiang Mai University. Research Center in Physics and Astronomy, Materials Science Research Center. Science and Technology Research Institute, and Department of Physics and Materials Science, Faculty of Science, Chiang Mai University are also acknowledged.

\section{REFERENCES}

1. Bediako M (2018) Pozzolanic potentials and hydration behavior of ground waste clay brick obtained from clamp-firing technology. Case Stud Constr Mater 8, 1-7.

2. Fernandez R, Martirena F, Scrivener KL (2011) The origin of the pozzolanic activity of calcined clay minerals: A comparison between kaolinite, illite and montmorillonite. Cem Concr Res 41, 113-122.

3. Seraj S, Ferron RD, Juenger MCG (2016) Calcining natural zeolites to improve their effect on cementitious mixture workability. Cem Concr Res 85, 102-110.
4. Nikolov A, Rostovsky I, Nugteren H (2017) Geopolymer materials based on natural zeolite. Case Stud Constr Mater 6, 198-205.

5. Abdel-Ghani NT, Elsayed HA, Abdel-Moied S (2018) Geopolymer synthesis by the alkali-activation of blastfurnace steel slag and its fire-resistance. $H B R C$ J 14, 159-164.

6. Alehyen S, Achouri ME, Taibi M (2017) Characterization, microstructure and properties of fly ash-based geopolymer. J Mater Environ Sci 8, 1783-1796.

7. Davidovits J (1988) Geopolymers of the first generation: siliface-process, geopolymer. Geopolymer $\mathbf{8 8}$, 49-67.

8. Lin L, Wang S, Zhu Z (2006) Main factors affecting mechanical characteristics of geopolymer revealed by experimental design and associated statistical analysis. J Colloid Interface Sci 300, 52-59.

9. Huang Y, Han M (2011) The influence of $\mathrm{Al}_{2} \mathrm{O}_{3}$ addition on microstructure, mechanical and formaldehyde adsorption properties of fly ash-based geopolymer products. $J$ Hazard Mater 193, 90-94.

10. He P, Jia D, Wang S (2013) Microstructure and integrity of leucite ceramic derived from potassiumbased geopolymer precursor. J Eur Ceram Soc 33, 689-698.

11. Schmücker M, MacKenzie KJD (2005) Microstructure of sodium polysialate siloxo geopolymer. Ceram Int 31, 433-437.

12. Duxson P, Lukey GC, Deventer JSJ (2007) Physical evolution of Na-geopolymer derived from metakaolin up to $1000^{\circ} \mathrm{C}$. J Mater Sci 42, 3044-3054.

13. Ferone C, Roviello G, Colangelo F, Cioffi R, Tarallo O (2013) Novel hybrid organic-geopolymer materials. App Clay Sci 73, 42-50.

14. Zhang Z, Provis JL, Reid A, Wang H (2014) Geopolymer foam concrete: An emerging material for sustainable construction. Constr Build Mater 56, 113-127.

15. Verdolotti L, Liguori B, Capasso I, Errico A, Caputo D, Lavorgna M, Iannace S (2015) Synergistic effect of vegetable protein and silicon addition on geopolymeric foams properties. J Mater Sci 50, 2459-2466.

16. Bai C, Franchin G, Elsayed H, Conte A, Colombo P (2016) High strength metakaolin-based geopolymer foams with variable macro-porous structure. $J$ Eur Ceram Soc 36, 4243-4249.

17. Škvára F, Šulc R, Tišler Z, Skřičík P, šmilauer V, Cílová ZZ (2014) Preparation and properties of fly ash-based geopolymer foams. Ceram Silikaty 58, 188-197.

18. Prud'homme E, Michaud P, Joussein E, Peyratout C, Smith A, Arrii-Clacens S, Clacens JM, Rossignol $S$ (2010) Silica fume as porogent agent in geomaterials at low temperature. J Eur Ceram Soc 30, 1641-1648. 
19. Ducman V, Korat L (2016) Characterization of geopolymer fly-ash based foams obtained with the addition of $\mathrm{Al}$ powder or $\mathrm{H}_{2} \mathrm{O}_{2}$ as foaming agents. Mater Charact 113, 207-213.

20. Bai C, Franchin G, Elsayed H, Zaggia A, Conte L, Li H, Colombo P (2017) High-porosity geopolymer foams with tailored porosity for thermal insulation and wastewater treatment. J Mater Res 32, 3251-3259.

21. Bai C, Colombo P (2018) Processing, properties and applications of highly porous geopolymers: A review. Ceram Int 44, 16103-16118.

22. Yun-Ming L, Cheng-Yong H, Mustafa M, Bakri A, Hussin K (2016) Structure and properties of clay based geopolymer cements: A review. Prog Mater Sci 83, 595-629.

23. Bai C, Colombo P (2017) High-porosity geopolymer membrane supports by peroxide route with the addition of egg white as surfactant. Ceram Int 43, 2267-2273.

24. Bai C, Ni T, Wang Q, Li H, Colombo P (2018) Porosity, mechanical and insulating properties of geopolymer foams using vegetable oil as the stabilizing agent. $J$ Eur Ceram Soc 38, 799-805.

25. Cilla MS, Morelli MR, Colombo P (2014) Open cell geopolymer foams by a novel saponification/peroxide/gelcasting combined route. J Eur Ceram Soc 34, 3133-3137.

26. Cilla MS, Innocentini MDM, Morelli MR, Colombo P (2017) Geopolymer foams obtained by the saponification/peroxide/gelcasting combined route using different soap foam precursors. J Am Ceram Soc 100, 3440-3450.

27. Anneken DJ, Both S, Christoph R, Fieg G, Steinberner U, Westfechtel A (2006) Fatty acids. In: Ullmann's Encyclopedia of Industrial Chemistry, Wiley-VCH, Germany.

28. Bockisch M (1998) Fats and Oils Handbook, AOCS Press, MA, USA.

29. Gunstone FD (2004) The Chemistry of Oils and Fats: Sources Composition Properties and Uses, Blackwell Publishing Ltd., NJ, USA.
30. Shahidi F (2005) Bailey's Industrial Oil and Fat Products, Wiley-Interscience, NJ, USA.

31. Toscano G, Riva G, Foppa Pedretti E, Duca D (2012) Vegetable oil and fat viscosity forecast models based on iodine number and saponification number. Biomass Bioenerg 46, 511-516.

32. Silva RC, Cotting LN, Poltronieri TP, Balcão VM, Gioielli LA (2009) Physical properties of structured lipids from lard and soybean oil produced by enzymatic interesterification. Ciênc Tecnol Aliment Campinas 29, 652-660.

33. Rohman A, Triyana K, Sismindari Y, Erwanto Y (2012) Differentiation of lard and other animal fats based on triacylglycerols composition and principal component analysis. Int Food Res $J$ 19, 475-479.

34. Azouz A (2011) Nutritional evaluation of children Egyptian school meal: I - Fat sources and fatty acids profile. Ann Agric Sci 56, 73-76.

35. Kaewapai K, Lertcumfu N, Jaita P, Manotham S, Tunkasiri T, Malasri P, Rujijanagul G (2019) Preparation and characterization of ceramic waste-based geopolymer ceramic composites for substrate culture application. Key Eng Mater 798, 194-199.

36. Masia G, Rickard WDA, Vickers L, Bignozzi MC, Riessen A (2014) A comparison between different foaming methods for the synthesis of light weight geopolymers. Ceram Int 40, 13891-13902.

37. Zhang Z, Provis JL, Reid A, Wang H (2014) Geopolymer foam concrete: An emerging material for sustainable construction. Constr Build Mater 56, 113-127.

38. Ryshkewitch E (1953) Compression strength of porous sintered alumina and zirconia. J Am Ceram Soc 36, 65-68.

39. Bai C, Deng X, Li J, Jing Y, Jiang W (2014) Preparation and properties of mullite-bonded porous $\mathrm{SiC}$ ceramics using porous alumina as oxide. Mater Charact 90, 81-87.

40. Li J, Lin H, Li J (2011) Factors that influence the flexural strength of SiC-based porous ceramics used for hot gas filter support. J Eur Ceram Soc 31, 825-831. 